\title{
How Van Panchayat Rule Systems and Resource Use Influence People's Participation in Forest Commons in the Indian Himalayas
}

\author{
Kazuyo Nagahama ${ }^{1}$, Kaoru Saito ${ }^{1}$, Hirokazu Yamamoto ${ }^{1}$, Yasukazu Hama ${ }^{1}$, Hem Gairola $^{2}$, Prakash $_{\text {Singh }}^{3}$ \& \\ Randeep Rakwal ${ }^{4,5}$ \\ ${ }^{1}$ Graduate School of Frontier Sciences, The University of Tokyo, Chiba, Japan \\ ${ }^{2}$ Garhwal Environment and Education Society, Uttarakhand, India \\ ${ }^{3}$ Himmotthan Society, Dehradun, Uttarakhand, India \\ ${ }^{4}$ Faculty of Health and Sport Sciences, University of Tsukuba, Ibaraki, Japan \\ ${ }^{5}$ GRADE (Global Research Arch for Developing Education) Academy Private Limited, Birgunj, Nepal \\ Correspondence: Kazuyo Nagahama, School of Management, Northern, Graduate School of Frontier Sciences, \\ The University of Tokyo, Environmental Building 407, 5-1-5 Kashiwanoha, Kashiwa 277-8563, Chiba, Japan. \\ E-mail: nagahama.kazuyo@s.nenv.k.u-tokyo.ac.jp
}

Received: December 18, 2018

doi:10.5539/jsd.v12n2p56
Accepted: February 18, 2019 Online Published: March 30, 2019

URL: https://doi.org/10.5539/jsd.v12n2p56

\begin{abstract}
Van Panchayats (VPs) are self-initiated forest management groups institutionalized since 1931 in the Himalayan Uttarakhand state of North India. VPs are considered to be successful case of Community-Based Forest Management (CBFM) despite an observed decline in VP practice around the 1990s. This study clarifies CBFM in the context of local rules, forest resource use and people's participation. It reveals the possible factors behind better resource management of forest commons use from four VPs in Uttarakhand. A multi-dimensional research approach was followed comprising a literature review of the state forest department data, forest inventory, interviews with village leaders as snowball samplings in several villages, and semi-structured interviews with villagers/house-holders. Results showed that local rules are different depending on the villages expect for prohibited timber logging. The most useful tree species for local people was Banji oak (Quercus leucotrichophora) and every village had an oak forest which was utilized for fuelwood and fodder for daily livelihoods. VP forest size and the basal area of trees also influenced people's participation in forest management. Much larger size of the VP forest land is declining due to the people's de-motivation for forest management. Furthermore, a higher education of the householder increased the level of participation. Transparency of Management Committee (MC) for the VP members is an important aspect. To summarize, availability and utilization of the valuable forest resources and its management by villagers following local rules and the VP system was considered to influence people's participation in the forest commons.
\end{abstract}

Keywords: community-based forest management (CBFM), decentralized forest resources, people's participation, local governance, management committee (MC)

\section{Introduction}

\subsection{Emergence of Community-Based Forest Management (CBFM)}

Until the late 1980s, national forest policies in India emphasized optimization of commercial forestry, which prohibited local villagers' access to forests (Ota et al. 2014). The result was rapid and widespread forest degradation, exposing the failure of top-down state forest resource management policies. Frequent conflicts also arose between Forest Department (hereafter, FD) and local forest users, such as the villagers. It was then that the local government became aware of the important roles forests play in supporting local people's livelihoods (Saito-Jensen 2008). In the 1990s, the forestry sector was gradually decentralized, creating greater efficiency, accountability, and cost cutting (Agrawal and Ribot 1999). Hence, the local government began to acknowledge a certain right and authority of local communities to the management of state forests. This idea of Community-Based Forest Management (hereafter, CBFM) has been observed in developing countries, including India. 


\subsection{Background of Van Panchayat (VP) and Issues}

The state of Uttarakhand in North West India was practicing decentralized forest management since the British colonial period. This was done by a self-initiated forest protection group called Van panchayat (hereafter VP; "Van" means forest in Hindi, "Panchayat" means village council); currently, VP is governed by VP rules, first published in 1931, and in 1976, 2001 and in 2005 (UFD 2005). Accordingly, all villagers are members of the VP upon their approval by a Sub-Divisional Magistrate under the state Revenue Department (RD). The members are collectively referred to as the general body (hereafter, GB), which selects the Management Committee (hereafter, MC) members through a democratic process. The VPs are the best examples of age-old institutions (Ballabh et al. 2002; Gairola and Negi 2011). Both institutions have emerged out of persistent conflicts between the people and the government regarding their control over forest resources (Guha 1983; Singh and Ballabh 1991).

According to Agrawal (2005), VPs provided good examples of decentralized forest resources management that benefited local communities, and defined those forest commons which provided an effective governance of the resource system based on the theory of commons and property rights (Agrawal 2007). However, there is a steady decline in VP practice and a quantitative and qualitative decline in the once dense and well-managed forests in the central Himalayas (Balooni et al. 2007). Local governance over forests became disempowered, and the power/influence of the VP system in general is in decline because of increasing FD control, resulting in an overall loss of autonomy and intensified conflicts within and among MCs of the VPs (Ballabh et al. 2002). Despite this research, there is still a lack of studies focusing on different cases of VPs, and the conditions behind their failure or success or importantly the reasons behind people's continued participation in cases of successfully operating VPs.

In a developing country like India, it is not possible to close down or demarcate a forest for use of the state alone because many people depend on it (the forest) for basic needs like fuelwood, timber, fodder, medicines, etc. Unless people's dependence on the forest is reduced, i.e., by giving them better opportunities outside the forest, it is unlikely that forests can be managed as a state property regime. Thus, in the present situation, sustainable forest management can be achieved by seeking people's participation (Lise 2000). The emergence and establishment of village-level institutions could help in protecting and regenerating the forest. This requires the collective action of all involved parties: state, non-governmental organizations (hereinafter, NGO), and people. People's participation is the key to VP success and continuity, and this is one of the reasons for initiating studies, as mentioned below, on VP governance in the Indian Himalaya.

\subsection{Exploring the Importance of People's Participation in Forest Management}

Regarding "successful" cases, a preliminary study was conducted as a case study of a VP (Nagahama et al. 2016a), which revealed the presence of a large oak forest in the village VP to be one reason behind the good impact of the VP; i.e., in terms of forest utilization for the maintenance of people's livelihood and environmental conservation. Further, the study also identified a general lack of people's participation in VP meetings and micro-plan discussion, indicating that local people were not much concerned with forest management despite the fact that "D village" VP was considered a "successful" case by the FD officer. "Successful" in this instance meant the VP leader provided strong leadership and full-knowledge of the land; i.e., the D village VP was both an active and successful case for this study to analyze people's perception.

Nevertheless, the previous study had some limitations. Although the work of Lise (2000) was a well-rounded study that examined forest management in general, it was not specifically targeted to the VPs or Indian Himalaya. The preliminary study of Nagahama (2016a) comprised only one village and consequently had less data with which to look into the effect of people's participation in CBFM. Therefore, it was necessary to investigate more cases of local governance at multiple villages in order to have a better understanding of VP governance and to further clarify factors influencing people's participation in successful CBFM in the Indian Himalaya. Hence, building on previous research, the current study used the semi-structured interview approach obtaining the voices of both higher and lower classes including Scheduled Caste (hereafter, SC) along with a VP forest inventory.

This study targets the following research objectives: 1) to clarify the VPs local governance/system in four selected villages, 2) to analyze the extent of and reasons for people's participation in CBFM, and 3) to disclose the main factors for people's participation in forest management based on local forest governance for sustainable forest management.

\subsection{Forest Management, VPs and Relation to the Research Design}

The present study utilizes a survey of four successful VPs in villages from three districts (Tehri, Chamoli and Almora) of the Uttarakhand state (Fig. 1), with interviews and forest inventory methods named "I \& I method" 
(Fig. 2). Additional use of the forest inventory approach to this study made it possible to identify and link forest resources in motivating the villager's contribution to the VP system of CBFM. The results from this study provide new insight into the extent of people's participation in VP forest utilization, management of forest commons and local governance.

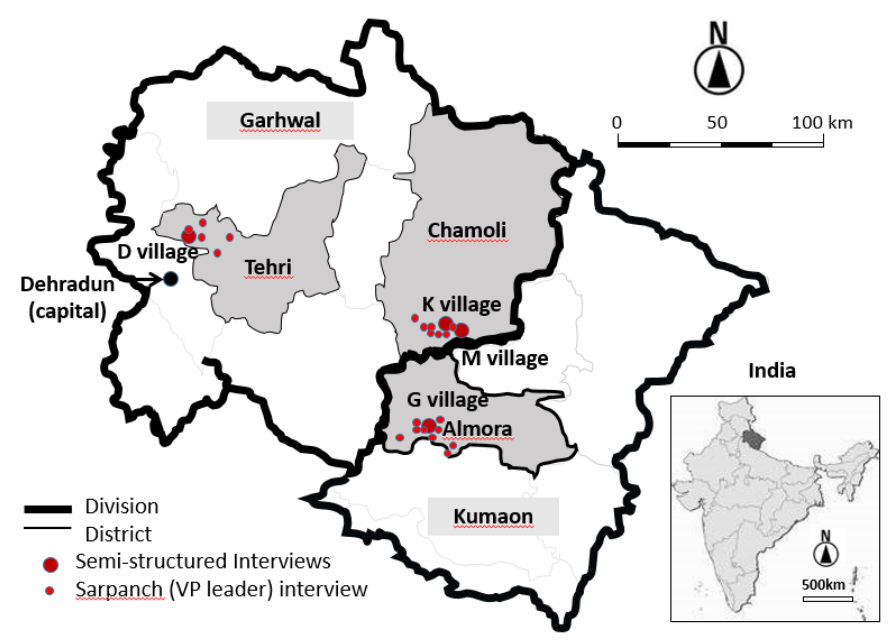

Figure 1. Map of the state of Uttarakhand and study sites

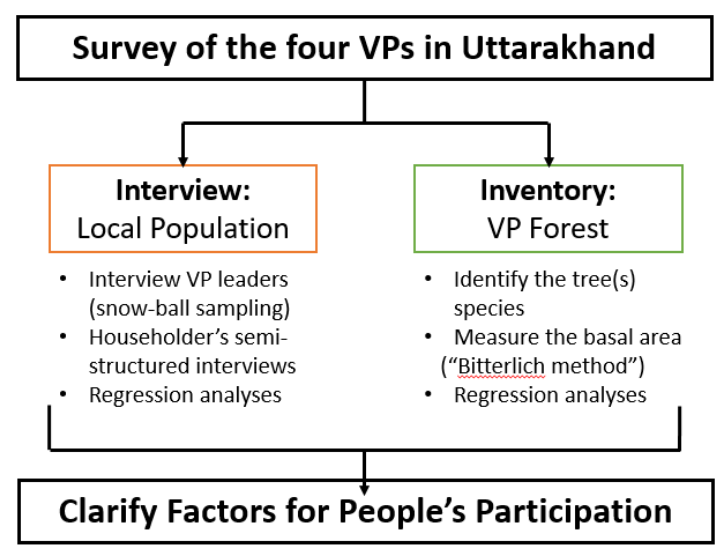

Figure 2. Interview and Inventory (I \& I) method

\section{Method}

\subsection{Districts Selection in the State of Uttarakhand}

The VPs were enacted only in Uttarakhand, and targeted in this study. Table 1 shows the data for all VPs in Uttarakhand state according to the "VP Atlas" (UFD 2007) and "Uttarakhand Forest Statistics" (UFD 2014) with each district's population data based on the Census 2011 (Government of India 2011). According to Table 1, three districts were selected with the following criteria: a) area size of VP forest and b) revenue from VPs, which have much impact for forest management and comparison. Regarding a), the Tehri district was selected as it has the smallest VP forest area per village and there was no revenue record due to its being a newly formed VP after the 1990's. Unlike Tehri, the Chamoli district has the largest recorded average village-level VP forest area compared to the other districts. Regarding b), the Almora district has the highest VP revenue; this means a VP forest could be managed to obtain better profits, however the population in Almora district has been decreasing. Also, Tehri and Dehradun districts generated less revenue than Almora district. Therefore, the field survey was performed at VPs in the Tehri-Garhwal, Chamoli and Almora districts of Uttarakhand state. 
Table 1. VP information in Uttarakhand state

\begin{tabular}{|c|c|c|c|c|c|c|c|c|c|c|c|c|c|}
\hline Division & District & $\begin{array}{l}\text { Total } \\
\text { Area } \\
(\mathrm{km} 2)\end{array}$ & $\begin{array}{l}\text { Popu- } \\
\text { lation } \\
\text { (thou- } \\
\text { sand) }\end{array}$ & $\begin{array}{c}\text { Popu- } \\
\text { lation } \\
\text { increase } \\
(\%)\end{array}$ & $\begin{array}{c}\text { Total } \\
\text { Forest } \\
\text { Area } \\
(\mathrm{km} 2)\end{array}$ & $\begin{array}{l}\text { Village } \\
\text { number }\end{array}$ & $\begin{array}{c}\text { VP } \\
\text { number }\end{array}$ & $\begin{array}{l}\text { VP } \\
\text { forest } \\
\text { area } \\
(\mathrm{km} 2)\end{array}$ & $\begin{array}{c}\text { VP } \\
\text { Total } \\
\text { Revenue } \\
\text { (thou. } \\
\text { Rp.) }\end{array}$ & $\begin{array}{c}\text { VP / } \\
\text { Village } \\
\text { number } \\
\text { ratio } \\
(\%)\end{array}$ & $\begin{array}{c}\text { VP area/ } \\
\text { Total } \\
\text { Forest } \\
\text { Area (\%) }\end{array}$ & $\begin{array}{l}\text { VP area/ } \\
\text { VP no. } \\
\text { (km2) }\end{array}$ & $\begin{array}{c}\text { VP } \\
\text { revenue/ } \\
\text { number } \\
\text { (Rp.) }\end{array}$ \\
\hline \multirow{7}{*}{ Garhwal } & Tehri & 3,642 & 620 & 2.4 & 3,216 & 1,868 & 1,332 & 132 & 0 & 71.31 & 4.1 & 0.10 & 0 \\
\hline & Uttarakashi & 8,016 & 330 & 11.9 & 7,217 & 710 & 644 & 73 & 660 & 90.70 & 1.0 & 0.11 & 1025 \\
\hline & Pauri Garhwal & 5,329 & 790 & -1.4 & 3,851 & 3,483 & 2,431 & 528 & 1,260 & 69.80 & 13.7 & 0.22 & 518 \\
\hline & Dehradun & 3,088 & 1,700 & 32.3 & 2,018 & 771 & 215 & 77 & 0 & 27.89 & 3.8 & 0.36 & 0 \\
\hline & Rudraprayag & 1,984 & 240 & 6.5 & 1,804 & 690 & 574 & 207 & 520 & 83.19 & 11.5 & 0.36 & 906 \\
\hline & Chamoli & 8,030 & 390 & 5.7 & 5,061 & 1,252 & 1,082 & 1,884 & 5,790 & 86.42 & 37.2 & 1.74 & 5351 \\
\hline & Haridwar & 2,360 & 1,890 & 30.6 & 724 & 636 & 0 & 0 & 0 & NR & NR & NR & NR \\
\hline \multirow{7}{*}{ Kumaon } & Almora & 3,139 & 620 & -1.3 & 2,362 & 2,294 & 2,194 & 699 & 41,400 & 95.64 & 29.6 & 0.32 & 18870 \\
\hline & Bageshwar & 2,246 & 260 & 4.2 & 1,102 & 948 & 822 & 388 & 12,690 & 86.71 & 35.2 & 0.47 & 15438 \\
\hline & Champawat & 1,766 & 260 & 15.6 & 1,323 & 721 & 629 & 312 & 440 & 87.24 & 23.6 & 0.50 & 700 \\
\hline & Pithoragarh & 7,090 & 480 & 4.6 & 2,053 & 1,678 & 1,666 & 871 & 1,650 & 99.28 & 42.4 & 0.52 & 990 \\
\hline & Nainital & 4,251 & 950 & 25.1 & 2,982 & 1,160 & 495 & 281 & 8,800 & 42.67 & 9.4 & 0.57 & 17778 \\
\hline & Udham Singh Nagar & 2,542 & 1,650 & 33.5 & 938 & 708 & 0 & 0 & 0 & NR & NR & NR & NR \\
\hline & Total & 53,483 & 10,180 & 13.1 & 34,651 & 16,919 & 12,089 & 5,449 & 73,210 & 71.45 & 15.7 & 0.45 & 6056 \\
\hline
\end{tabular}

\subsection{Village Selection and Study Design}

As for the three different districts, four villages were selected from multiple villages (and VPs) visited. The villages were selected for a preliminary snowball sampling by talking to the sarpanch who was also the VP leader, and some villagers. Selected four villages (Table 2) were district-wise which had potential positive characteristics, such as the MC created micro-plan for forest management, chowkidar (forest guard), and NGO support. Furthermore, comparatively better performing and fell within a range (1931 to 1990 and 1990 till present) of different established years. On the other hand, other 20-VPs were not selected for the following case study due to the negative condition that the village head (sarpanch) did not live in the village, that there were less than eight members of the MC, and that the forest condition was worse than other villages. Data were broadly collected under two categories of house-hold interviews and forest inventories (Fig. 2) such as measuring tree species and basal area in the VP forest. Furthermore, regression analyses were done in order to identify the factors/characteristics of people's participation in forest management.

Table 2. General information of the selected field sites

\begin{tabular}{|c|c|c|c|c|c|c|}
\hline Plot number & 1 & 2 & 3 & 4 & & \\
\hline VP & $\mathrm{D}$ & $\mathrm{G}$ & $\mathrm{K}$ & $M$ & Average & Total \\
\hline Division & Garhwal & Kumaon & Garhwal & Garhwal & - & - \\
\hline District & Tehri & Almora & Chamoli & Chamoli & - & - \\
\hline Altitude & 1850 & 1850 & 1450 & 1400 & 1638 & - \\
\hline Total HH(Household) & 51 & 22 & 32 & 35 & 35 & 140 \\
\hline Sample number & 41 & 19 & 31 & 26 & 29 & 117 \\
\hline Recover rate & $80 \%$ & $86 \%$ & $97 \%$ & $74 \%$ & $84 \%$ & - \\
\hline SC(Scheduled Caste) & 22 & 3 & 0 & 1 & 6.5 & 26 \\
\hline Rajiput & 10 & 9 & $\begin{array}{l}25: \text { Rawat } \\
\text { 6: Negi }\end{array}$ & $\begin{array}{l}\text { 1: Bisht } \\
\text { 5:Rawat } \\
\text { 18: Negi }\end{array}$ & 9.5 & 19 \\
\hline Bhramin & 9 & 7 & 0 & 0 & 4.0 & 16 \\
\hline Population & 348 & 158 & 129 & 147.0 & 196 & 782 \\
\hline Female & 181 & 46 & 62 & NA & NA & NA \\
\hline Male & 167 & 72 & 67 & NA & NA & NA \\
\hline Ave. family number & 6.8 & 7 & 6 & 6.4 & 6 & 25 \\
\hline Established & 1993 & 1937 & 1972 & 1953 & 1964 & - \\
\hline MC member(Gender)* & $M: 5, F: 4$ & $\mathrm{M}: 5, \mathrm{~F}: 4$ & $\mathrm{M}: 5, \mathrm{~F}: 4$ & $M: 6, F: 3$ & M:5.6. F:3.8 & $\mathrm{M}: 21, \mathrm{~F}: 15$ \\
\hline MC member(Caste)* & GC:6, SC:3 & GC:6, SC:3 & GC:9 & GC:9 & GC:7.5, SC:1.5 & GC:30. SC:6 \\
\hline Sarpanch(VP leader) & Male & Female & Male & Male & - & - \\
\hline Period of VP leader (year) & 19 & 10 & 4 & 18 & 12.75 & - \\
\hline Forest Watchman & NO & Male & Male & Male & - & - \\
\hline
\end{tabular}

* MC: Management Committee 


\subsection{Data Collection}

Data was collected as semi-structured interviews of representatives of a household using a questionnaire sheet, and through householders with local interpreters (Note 1) using a pretested extensive questionnaire. Households were randomly selected from each village (Note 2), and more than 80 percent of interviews were completed in different districts in 2012-2015 (Table 2) (Note 3). Additional data collection consisted of the measurement of tree species and the basal area survey which was implemented in these VP forests in June-July, 2015.

Table 3. Period of field survey in selected VP villages

\begin{tabular}{ccccc}
\hline Name of VP & D village & G village & K village & M village \\
\hline $\begin{array}{c}\text { Period of semi-structured } \\
\text { interview }\end{array}$ & July-August, 2012 & October, 2013 & June, 2014 & June, 2015 \\
\hline June, 2014 & June, 2014 & & June, 2015 \\
\hline
\end{tabular}

As for measuring biomass, the "Bitterlich method" (Note 4) which was angle-count sampling (ACS), was utilized for trees in a forest inventory. ACS theory and idea is expressed by equation (Bitterlich 1984).

$$
\mathrm{G}=\mathrm{z} \mathrm{k}
$$

In equation (1), $G$ is the basal area density around a point in the forest, $\mathrm{z}$ is the number of trees counted from that point in accordance with certain rules, and $\mathrm{k}$ is the basal-area factor. The method needs to have at least 5 plots in the same type of forest for data collection. As for the biomass assessment/inventory, plot sampling which needs quadrat sampling is much more common. However, plotless sampling is better for evaluation by the same person (Bitterlich 1984) in the short-term. Bitterlich methods are a more established method for plotless sampling and for estimating basal area per hectare.

\subsection{Regression Analyses}

This is a method for translating a large set of variables into a few independent choice variables, by separating participatory indicators into a set of principal components, known as factors (Harman 1967; Lise 2000). Each factor represents an independent choice. Variables with a coefficient in absolute value above 0.5 are said to be dominating in a factor. Another rule is that all factors with an eigen-value larger than one should be used in the analysis. For measuring attitudes toward VP, the respondents are asked a set of questions, which are interpreted as indicators of participation. These indicators are scaled as an integer value in a range from one to five, where one means total disagreement and five means total agreement with one particular aspect of participation with respect to the VP. This analysis identifies under which conditions a person is most likely to participate in forest management. Links between several socio-economic variables and some variables regarding forest are found with support of multiple regression analyses. The following equation is estimated for 18 explanatory variables.

$$
\begin{gathered}
\theta=\alpha+\beta 1 \text { AGE }+\beta 2 \text { EDU }+\beta 3 \text { FAMLNO }+\beta 4 \text { FEMRATIO }+\beta 5 \text { DISTOVP } \\
+\beta 6 \text { MCMEMBER }+\beta 7 \text { APWORK }+\beta 8 \text { USELPG }+\beta 9 \text { BRAHMIN }+\beta 10 \text { SC } \\
+\beta 11 \text { INWORK }+\beta 12 \text { OWNANI }+\beta 13 \text { PRITREE }+\beta 14 \text { SARPLEAD }+\beta 15 \text { VPESTABL } \\
+\beta 16 \text { RELATION }+\beta 17 \text { BIOMASS }+\beta 18 \text { VPINOAK }+ \text { error }
\end{gathered}
$$

In equation (2), $\theta$ is the level of participation, $\alpha$ is a constant, and $\beta$ is the coefficient of a socio-economic variable. Table 4 shows the meaning of the variables.

Besides running a regression equation (2), the descriptive variables are also checked for multicollinearity by excluding correlated variables. 
Table 4. Variables used for analysis

\begin{tabular}{|c|c|c|}
\hline & Jariable & Meaning and definition \\
\hline \multicolumn{2}{|c|}{$\begin{array}{l}\text { Explained variable: } \\
\qquad \theta\end{array}$} & $\begin{array}{l}\text { The level of participation, ratio of participation to } \\
\text { meeting for participatory indicators }\end{array}$ \\
\hline \multicolumn{3}{|c|}{ Explanatory variables: } \\
\hline \multirow{13}{*}{$\begin{array}{c}\text { House- } \\
\text { hold } \\
\text { level }\end{array}$} & AGE & Age of householder \\
\hline & EDU & Years of schooling of householder \\
\hline & FAMLNO & Number of family/household \\
\hline & FEMRATIO & Female ration in household \\
\hline & DISTOVP & Distance to VP forest \\
\hline & MCMEMBER & Before/present MC member \\
\hline & APWORK & Another place for work \\
\hline & USELPG & Use of LPG (lower number means use less of LPG) \\
\hline & BRAHMIN & Highest Caste group \\
\hline & SC & Lowest caste group \\
\hline & INWORK & Income per capita (rupees/month) \\
\hline & OWNANI & Owning animals (ratio) \\
\hline & PRITREE & Number of private oak trees \\
\hline \multirow{5}{*}{$\begin{array}{l}\text { Village } \\
\text { level }\end{array}$} & SARPLEAD & Sarpanch leadership \\
\hline & VPESTABL & When VP has established \\
\hline & RELATION & Relationship of villagers \\
\hline & BIOMASS & Biomass volume in the village \\
\hline & VPINOAK & Oak in VP forest \\
\hline
\end{tabular}

\section{Results}

\subsection{Comparison of Local Rules}

Every VPs had local rules regarding forest use. Depending on villages, the volume of rules was different (Table 5). D village VP had fewer rules than $\mathrm{K}$ village VP. There were chowkidars in most of the villages, except for $\mathrm{D}$ village. A chowkidar is a forest guard and employed by the MC of each VP. In the case of K village, every household paid 20 rupees per month to employ the chowkidar. In M village, the chowkidar could obtain 50 rupees a day for ten days per month. The $\mathrm{K}, \mathrm{G}$ and $\mathrm{M}$ village VPs were supported by government or NGOs. These organizations supported the VP's MC in promoting active forest management such as by making an implementation plan and a micro-plan. Focusing on the K village VP, which has the most specific rules, the VP forest area was divided into three zones (Fig. 3). One part was open for grazing every year, while the other two parts, which both consisted of a dense forest zone, alternated in usage. When one area was open, it was used for green fodder collection in November and December, and for the lopping of fuel wood in December and January, while the other area remained closed. In the following year, the utilization of the VP forest zone was reversed, and the closed forest was opened under the same rules of usage. Following the first year rules of closed forest, the opened forest of the first year was closed during the second year. These local rules were modified depending on the condition of the forest.

Table 5. System of the local VP rules in villages

\begin{tabular}{clccc}
\hline Local Rules & D village & G village & K village & M village \\
\hline Logging & Prohibited & Prohibited & Prohibited & Prohibited \\
\hline Lopping & Permitted & Prohibited & $\begin{array}{c}\text { Prohibited in Dec. } \\
\text { to Jan. }\end{array}$ & Permitted \\
\hline Grazing animals & Permitted & Permitted & Permitted & Permitted \\
\hline $\begin{array}{c}\text { Grass cutting } \\
\text { branches/twigs/leaves }\end{array}$ & Permitted & Permitted & Permitted & Permitted \\
\hline Regulated period & Permitted & Permitted & $\begin{array}{c}\text { Prohibit in Nov to Dec } \\
\text { at some places }\end{array}$ & Permitted \\
\hline Regulated place & No & No & $\begin{array}{c}\text { Close: Feb-Oct. } \\
\text { by each area }\end{array}$ & No \\
\hline $\begin{array}{c}\text { Supporting from organization } \\
\text { NGO }\end{array}$ & No & No & $\begin{array}{c}\text { Second year: Closed } \\
\text { by each area }\end{array}$ & No \\
\hline from CAMPA & from JFM and CAMPA \\
\hline
\end{tabular}

NGO: Non-Governmental Organization; JFM: Joint Forest Management;

CAMPA: Compensatory Afforestation Management and Planning Authority; 


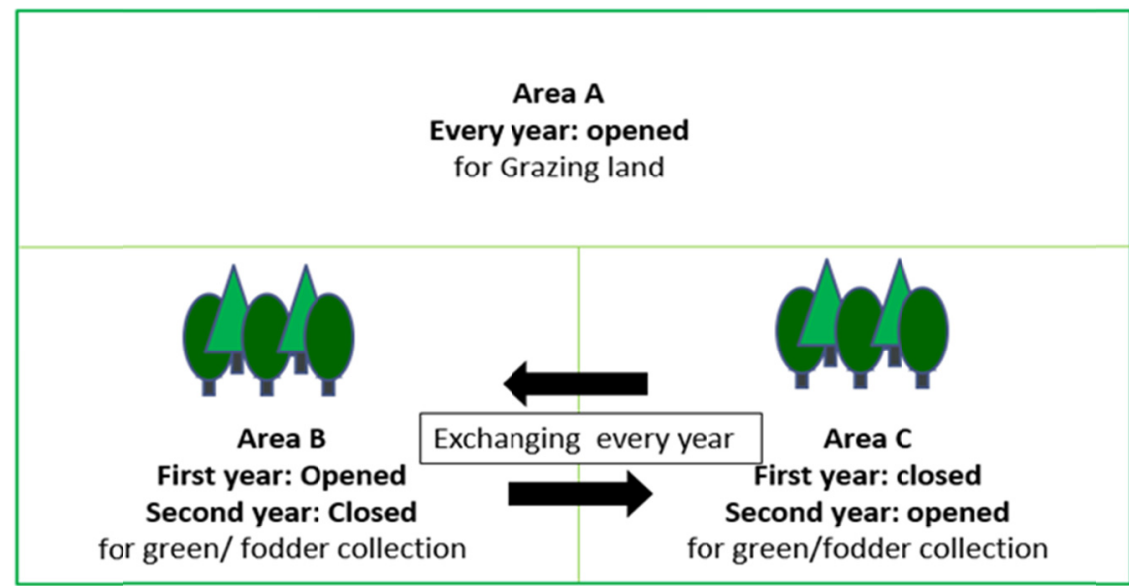

$\begin{array}{ll}\text { Forest Open: Nov-Jan } & \text { Nov- Dec: green fodder collection } \\ \text { Different utilization by each area } & \text { Dec-Jan: lopping of fire wood }\end{array}$

Figure 3. Local rules of Forest use in K village VP

\subsection{Forest Resource Use}

According to interviews, it was revealed that the branches and twigs of the oak trees were most commonly used for firewood, and the leaves were used for fodder in every village. Furthermore, the timbers were utilized as building materials in the traditional-type houses. In case of the pine trees in $G$ village, local people used the leaves/needles for carpeting in the animals sheds and extracted resin from the trees. As for the dominating species of each VP forest land (Table 6), Banji oak (Quercus leucotrichophora) was the dominant tree species in $\mathrm{D}$ village, whereas the Pine (Pinus roxburghii) and Box myrtle (Myrica esculenta) trees were also scattered in the forest. There are many species in G village VP forest but with mainly oak trees. In this area (in Almora, in the Kumaon division) more species could be observed than in Tehri Garhwal division. In K and M villages, VP forests in Chamoli district, which is between Kumaon and Garhwal, more Pine, Box myrtle (M. esculenta) and Rhododenron (Rhododenron arboretum) were observed as the primary trees. Planted forest was observed at the $M$ village VP, which has been managed under the Joint Forest Management (JFM) project for 15 years, and there were 5 ha of Cypress (Cupressus torulosa) trees for the purpose of commercial use. Alder (Alnus Nepalensis) and Angeri (Andromeda ovalifolia) trees were found as well.

Table 6. Species diversity and utilization pattern

man: Very dense forest, $\mathbf{m} \mathbf{m}:$ Moderate dense forest, $\mathbf{m}$ : Open forest, $\mathbf{m}$ : Scrub, Blank: Non forest )*

\begin{tabular}{|c|c|c|c|c|c|c|c|c|}
\hline \multirow[b]{2}{*}{ Plot } & \multirow[b]{2}{*}{ English } & \multicolumn{2}{|c|}{ Species } & \multirow[b]{2}{*}{ Use** } & \multicolumn{4}{|c|}{ VP } \\
\hline & & Hindi & Academic name & & D & G & $\mathrm{K}$ & $\mathrm{M}$ \\
\hline 1 & Oak & Banji & Quercus leucotrichophora & $2,3,4$ & man & $m$ & $\mathbf{m}$ & $\mathbf{m}$ \\
\hline 2 & Pine & Chir & Pinus roxburghii & 2,4 & a & $\mathbf{\square}$ & $\mathbf{m}$ & $\mathbf{\square}$ \\
\hline 3 & Box myrtle & Kaffal & Myrica esculenta & 1 (Fruit), 3, 5 & - & - & $\square$ & - \\
\hline 4 & Himalayan cedar & Deodar & Cedrus deodara & 4 & & a & & \\
\hline 5 & Rhododenron & Brans & Rhododenron arboretum & 1.3 & & घ & a & घ \\
\hline 6 & Pyrus & Mehal & Pyrus pashia & 1 (Fruit), 3 & & घ & & \\
\hline 7 & Berberis & Kilmora & Berberis asiatica & 3,5 & & घ & & \\
\hline 8 & Acacia & Khair & Acacia catechu & 3,4 & & - & & \\
\hline 9 & Acacia & Subabul & Acacia nilotica & 3 & & घ & & \\
\hline 10 & Alder & Utiis & Alnus Nepalensis & 4 & & & & $\mathbf{m}$ \\
\hline 11 & Cypress & Srai & Cupressus torulosa & 4 & & & & $\mathbf{m}$ \\
\hline 12 & Angeri & Ayar & Andromeda ovalifolia & 3 & & & & - \\
\hline
\end{tabular}

*: FSI (Forest Survey of India) defines that very dense forest is more than $70 \%$ of crown density, moderate forest is $40-70 \%$, open forest is $10-40 \%$, and scrub is less than $10 \%$.

Use**: 1: Food, 2: Firewood, 3: Fodder (leaf), 4: House, 5: Medicine 
Table 7 describes the result of basal area at VP forests. Both the basal area's volume and VP forest area per household in D village were the smallest, with total biomass (basal area) per household at $11.6 \mathrm{~m}^{2}$ and area of 0.39 ha; while the ratio of oak trees was the largest compared with the other villages (Table 8). Differing from this example, the VP forest per household in G village was 3.95 ha with total biomass (basal area) $110.7 \mathrm{~m}^{2}$ per household, and mainly dominated by oak trees. In K village, there was 1.75 ha of VP forest and $63.0 \mathrm{~m}^{2}$ of biomass volume per household, which comprised oak, pine and mixed forest. At M village, which was close to $\mathrm{K}$ village, 1.29 ha of VP forest and $43.9 \mathrm{~m}^{2}$ of biomass could be utilized by per household, and this included planted and mixed forest.

Table 7. Basal area and biomass volume of VP forest

D village (VP forest area: 20 ha; Total basal area: $592 \mathrm{~m}^{2}$ )

\begin{tabular}{c|cccccccc}
\hline Point No. & 1 & 2 & 3 & 4 & 5 & 6 & 7 & Average \\
\hline Tree number & 8 & 11 & 9 & 7 & 3 & 6 & 8 & 7.4 \\
\hline Oak tree & 8 & 11 & 8 & 7 & 3 & 6 & 8 & 7.3 \\
\hline Tree species & \multicolumn{8}{c}{ Oak dominated forest (Basal area $: 29.6 \mathrm{~m} / \mathrm{ha}$ ) } \\
\hline
\end{tabular}

G village (VP forest area: 87 ha; Total basal area: 2,436 m)

\begin{tabular}{|c|c|c|c|c|c|c|c|c|c|c|c|c|}
\hline Point No. & 1 & 2 & 3 & 4 & 5 & Average & 6 & 7 & 8 & 9 & 10 & Average \\
\hline Tree number & 10 & 5 & 7 & 7 & 6 & 7.0 & 7 & 5 & 2 & 9 & 12 & 7.0 \\
\hline Oak tree & 10 & 5 & 7 & 7 & 6 & 7.0 & 1 & 0 & 0 & 6 & 2 & 11.8 \\
\hline Tree species & & sal a & $\begin{array}{l}\text { ly d } \\
28 .\end{array}$ & $\begin{array}{l}\text { ate } \\
\text { na, } \mathrm{F}\end{array}$ & $\begin{array}{l}\text { oak } \\
\text { st ar }\end{array}$ & 55 ha) & & $\begin{array}{r}\text { Pine } \\
\text { (Basal }\end{array}$ & $: 28$ & ha, & $\begin{array}{l}\text { sanc } \\
\text { st ar }\end{array}$ & \\
\hline
\end{tabular}

K village (VP forest area: 56 ha; Total basal area: $2,016 \mathrm{~m})^{2}$

\begin{tabular}{c|cccccccccc}
\hline Point No. & 1 & 2 & 3 & 4 & 5 & 6 & 7 & 8 & 9 & Average \\
\hline Tree number & 8 & 6 & 6 & 11 & 10 & 9 & 11 & 13 & 7 & 9.0 \\
\hline Oak tree & 7 & 5 & 3 & 6 & 5 & 0 & 0 & 6 & 0 & 3.5 \\
\hline Tree species & \multicolumn{1}{c}{ Mixed forest, Pine forest, Oak dominates forest } & (Basal area : $\left.36.0 \mathrm{~m}^{2} / \mathrm{ha}\right)$ \\
\hline
\end{tabular}

Mvillage (VP forest area : 45 ha; Total basal area: 1,537 m)

\begin{tabular}{|c|c|c|c|c|c|c|c|c|c|c|c|c|c|}
\hline Point No. & 1 & 2 & 3 & 4 & 5 & Average & 6 & 7 & 8 & 9 & 10 & 11 & Average \\
\hline Tree number & 10 & 7 & 11 & 11 & 4 & 8.6 & 14 & 5 & 7 & 10 & 7 & 10 & 8.8 \\
\hline Oak tree & 1 & 6 & 1 & 2 & 0 & 2.0 & 0 & 0 & 0 & 0 & 0 & 0 & 0 \\
\hline Tree species & \multicolumn{6}{|c|}{$\begin{array}{l}\text { Mixed forest of Oak, Alder, and Cypress } \\
\text { (Basal area : } 34.4 \mathrm{~m} / \mathrm{ha} \text {, Forest area: } 40 \mathrm{ha} \text { ) }\end{array}$} & \multicolumn{7}{|c|}{5 ha ) } \\
\hline
\end{tabular}

Table 8. Volume of the basal areas and dependence of VP forest

\begin{tabular}{ccccc}
\hline Village & D & G & K & M \\
\hline Basal area (m/ha) & 29.6 & 28 & 36 & $32.2-34.4$ \\
VP forest area (ha) & 20 & 87 & 56 & 45 \\
Total basal area in VP forest area (m) & 592 & 2,436 & 2,016 & 1,537 \\
Number of total household & 51 & 22 & 32 & 35 \\
Basal area per household ( $\left.\mathrm{m}^{2} \mathrm{HH}\right)$ & 11.6 & 110.7 & 63.0 & 43.9 \\
VP forest area per household (ha/HH) & 0.39 & 3.95 & 1.75 & 1.29 \\
Use of firewood (\%) & 72.7 & 100.0 & 96.8 & 96.2 \\
Possesion of LPG) $(\%)$ & 58.5 & 28.6 & 70.1 & 7.7 \\
Consumption of firewood $(\mathrm{kg} / \mathrm{HH} /$ year) & 3965 & NA & 2738 & 5194 \\
Tree species & Oak dominated & Mainly Oak & Mixed & Mixed and Planted \\
\hline
\end{tabular}

LPG*: liquefied petroleum gas 
Figure 4 presents a landscape of each of the VP forests taken though a fish eyes camera and as presented as a picture/image.

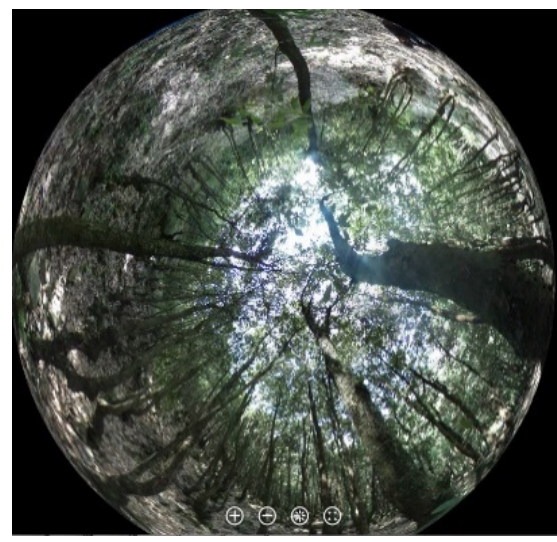

(1) D village (Point 3):

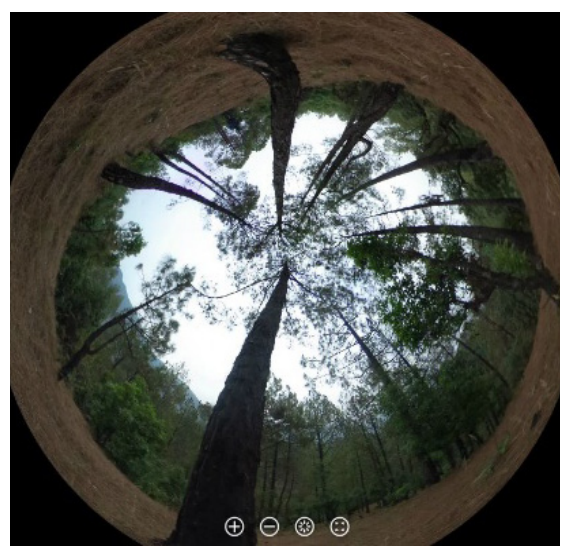

(3) K village (Point 6):

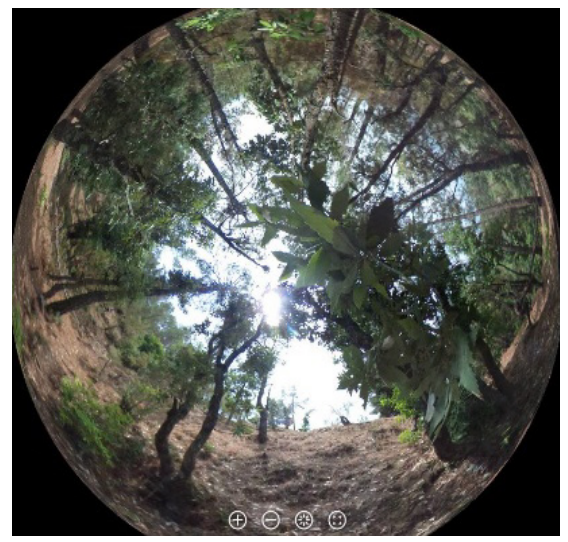

(2) G village (Point 5):

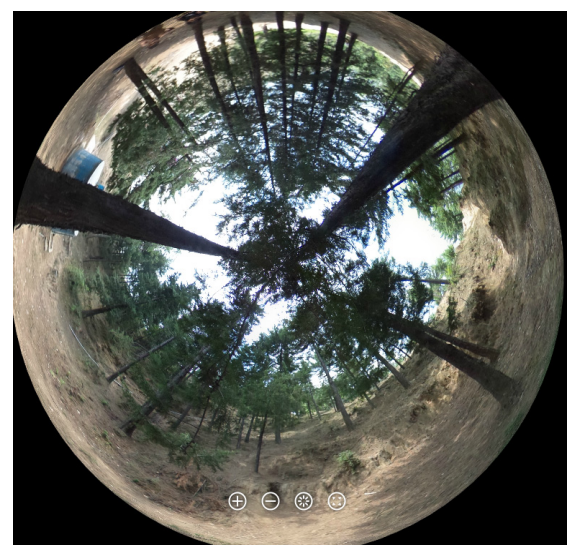

(4) M village (Point 9):

Figure 4. Landscape of the VP forest

\subsection{People's Participation in MC (Management Committee)}

According to the grouping of participatory indicators (Table 9), K and M village VPs were observed to have a high level of participation from the factors of "Importance of meeting", "Attendance of meeting", "Frequency of meeting", and "Transparency of meeting". All households were aware of the importance of VP meetings and were attending them every month. Moreover, the people (participants) had a voice and influence in the group's decisions.

Table 9. Grouping of participatory indicators (by ratio)

\begin{tabular}{ccccc}
\hline VP & D village & G village & K village & M village \\
\hline $\begin{array}{c}\text { Importance of meetings } \\
\text { (known as the VP Leader) }\end{array}$ & 0.9 & 0.21 & 1.00 & 0.92 \\
\hline Attendance of meetings & 0.76 & 0.71 & 1.00 & 0.92 \\
\hline Ability to influence decisions & 0.16 & 0.50 & 0.59 & 0.80 \\
\hline $\begin{array}{c}\text { Frequency of meeting } \\
\text { (monthly gathering) }\end{array}$ & 0.49 & 0.57 & 0.92 & 0.87 \\
\hline $\begin{array}{c}\text { Transparency of MC) } \\
\text { (management Committee) }\end{array}$ & 0.15 & 0.21 & 1.00 & 0.84 \\
\hline
\end{tabular}

MC*: Management Committee 
Regarding Table 10, MC members were selected, and several characteristics relating to the management of the forest were shown according to the factors. The ratio of SC numbers to each $\mathrm{MC}$, especially in D and G villages were low, and only a small ratio of households were found that had grazing animals, especially in K village; and where there were some people who were responsible for gathering animals to graze on the hillsides with better pasturage and the local householders entrusted these persons with their own cattle and goats.

Table 10. Management committee member's composition (by ratio)

\begin{tabular}{ccccc}
\hline VP & D village & G village & K village & M village \\
\hline Caste (SC* participation) & $0.22(0.54)$ & $0.25(0.16)$ & NA (0: no SC) & $0(0.08)$ \\
\hline Sudying at Outside & 0.38 & 0 & NA & NA \\
\hline Working at Outsite & 0.63 & 0.25 & 0.63 & 0.12 \\
\hline Closeness to VP forest $(\mathrm{km})$ & 0.29 & 0.75 & 0.13 & 0.67 \\
\hline Collecting Firewood & 1 & 1 & 1 & 0.13 \\
\hline Grazing animals & 0.63 & 0.75 & 0.5 & 0.17 \\
\hline Dish TV & 0.5 & 0.75 & 0.88 & 0.17 \\
\hline LPG & 0.38 & 0.5 & 0.44 & 0.33 \\
\hline Women's participation & 0.44 & 0.25 & 0 & 0 \\
\hline Woman VP leader & 0 & 1 & & \\
\hline
\end{tabular}

$\mathrm{SC}^{*}$ : Scheduled caste

According to the VP state Rules in Uttarakhand (UFD 2005), the VP leader, called the sarpanch, is a representative of 5 years following an open election. The D village leader, however, was elected, since the VP was first organized in 1993, and he has been in the position for nearly 20 years. At the same time, he was chosen as the block committee leader in this region from 151 villages, and with his present status and role, the FD officer recommended the VP for our pre-survey. The G village leader was a woman who was a university graduate and was active in organizing women's networks. She had been showcased in newspapers, and aggressively pursued connections with the local NGO (Note 5).

\subsection{Level of People's Participation}

According to the regression analysis presented in Table 11, some general patterns were indicated.

Table 11. Level of people's participation

\begin{tabular}{|c|c|c|c|c|c|c|c|c|c|c|}
\hline \multirow{3}{*}{$\begin{array}{c}\text { District } \\
\text { VP } \\
\end{array}$} & & & \multirow{2}{*}{\multicolumn{2}{|c|}{$\begin{array}{c}\text { Tehri } \\
D(n=42)\end{array}$}} & \multirow{2}{*}{\multicolumn{2}{|c|}{$\begin{array}{c}\text { Almora } \\
G(n=13)\end{array}$}} & \multicolumn{4}{|c|}{ Chamoli } \\
\hline & \multicolumn{2}{|c|}{ Overall ( $n=113$ ) } & & & & & \multicolumn{2}{|c|}{$K(n=31)$} & \multicolumn{2}{|c|}{$M(n=26)$} \\
\hline & Coef. & Std. Err. & Coef. & Std. Err. & Coef. & Std. Err. & Coef. & Std. Err. & Coef. & Std. Err. \\
\hline Constant & -0.490 & 0.305 & 0.090 & 0.482 & -0.136 & 0.099 & 0.523 & 0.520 & 0.155 & 0.385 \\
\hline AGE & 0.000 & 0.003 & -0.008 & 0.007 & 0.000 & 0.001 & 0.007 & 0.007 & 0.006 & 0.006 \\
\hline EDU & 0.006 & 0.008 & -0.001 & 0.021 & 0.025 & 0.005 & 0.028 & 0.019 & -0.027 & 0.025 \\
\hline FAMLNO & 0.002 & 0.009 & 0.016 & 0.032 & -0.003 & 0.004 & -0.013 & 0.021 & 0.009 & 0.050 \\
\hline FEMRATIO & -0.026 & 0.150 & 0.327 & 0.328 & -0.177 & 0.062 & -0.510 & 0.334 & 0.641 & 0.440 \\
\hline DISTOVP & 0.115 & 0.076 & 0.127 & 0.532 & 0.148 & 0.025 & 0.098 & 0.420 & 0.185 & 0.207 \\
\hline MCMEMBER & {$[0.234] * * *$} & 0.060 & {$[0.625]^{* *}$} & 0.230 & {$[0.195]^{*}$} & 0.030 & 0.057 & 0.113 & 0.000 & 0.116 \\
\hline APWORK & 0.003 & 0.030 & 0.036 & 0.173 & 0.003 & 0.011 & -0.131 & 0.097 & -0.010 & 0.085 \\
\hline USELPG & 0.064 & 0.080 & 0.079 & 0.215 & -0.004 & 0.030 & 0.168 & 0.179 & 0.664 & 0.670 \\
\hline BRAHMIN & 0.076 & 0.067 & 0.117 & 0.382 & 0.085 & 0.034 & 0.088 & 0.190 & 0.042 & 0.253 \\
\hline SC & -0.086 & 0.091 & 0.164 & 0.292 & -0.135 & 0.030 & 0.000 & (omitted) & 0.095 & 0.315 \\
\hline INWORK & 0.000 & 0.000 & 0.000 & 0.000 & 0.000 & 0.000 & 0.000 & 0.000 & 0.000 & 0.000 \\
\hline OWNANI & -0.009 & 0.015 & 0.022 & 0.042 & 0.021 & 0.011 & 0.033 & 0.037 & 0.055 & 0.056 \\
\hline PRITREE & 0.000 & 0.000 & NA & (omitted) & NA & (omitted) & 0.000 & 0.000 & 0.002 & 0.004 \\
\hline SARPLEAD & NA & (omitted) & NA & (omitted) & NA & (omitted) & NA & (omitted) & NA & (omitted) \\
\hline VPESTABL & {$[0.01]^{* * *}$} & 0.002 & NA & (omitted) & NA & (omitted) & NA & (omitted) & NA & (omitted) \\
\hline RELATION & {$[0.276]^{* * *}$} & 0.065 & NA & (omitted) & NA & (omitted) & NA & (omitted) & NA & (omitted) \\
\hline BIOMASS & {$[-0.004]^{* * *}$} & 0.001 & NA & (omitted) & NA & (omitted) & NA & (omitted) & NA & (omitted) \\
\hline VPINOAK & NA & (omitted) & NA & (omitted) & NA & (omitted) & NA & (omitted) & NA & (omitted) \\
\hline R-squared & 0.65 & & 0.75 & 5840 & & 9810 & & 097 & & 153 \\
\hline
\end{tabular}

*: $\mathrm{P}<0.1, * *: \mathrm{P}<0.05, * * *: \mathrm{P}<0.01$ 
Firstly, MC members were always positively linked to participation. Secondly, relationship at the local level stimulated people's participation in forest management. Thirdly, older VPs were positive in regard to participation. And lastly, a higher volume of biomass was indicative of being negative for people's participation. It should be noted that the level of participation in $\mathrm{K}$ village was best interpreted as higher than in the other VPs. The reason was the constant high numbers in $\mathrm{K}$ village, as shown in Table 11, and where many of the participatory factors were positive. Overall, the education of the householders was a positive indicator, and $\mathrm{K}$ and $M$ villages were also found with positive significant linkage; however, the other two villages (D and $G$ ) showed negative linkage. When we focused on the factor for LPG use, it was also positive except for M village. The link between the ratio of females to males in the family and participation was significantly negative overall, in both $\mathrm{K}$ village and $\mathrm{G}$ village. This means that the presence of women would decrease the level of participation at the management level. As for caste and participation, upper castes such as the Brahmin are significant and positive while SC was negative overall. In M village, people who belonged to SC tended to be negative in regards to their participation in management.

\section{Discussion}

This study presents comparisons of VPs' local governance in four selected villages (VPs), which were considered for the better use and management for forest commons, and examines the extent and reasons of people's participation in CBFM with interviews and forest inventory methods. The additional use of the forest inventory approach to this study made it possible to identify and link forest resources in motivating the villager's contribution to the VP system in forest commons. The results from this study illustrate the extent of people's participation in VP forest utilization, management and governance. It could also help answer as to what factors are necessary for sustainable forest management. The field sites (villages) were selected for different established years and districts, which were worked and managed by functioning VP and MC members. In these places, local rules existed and were different depending upon the villages expect for prohibited timber logging.

Regarding factors that influence people's participation in forest management, VPs have various positive characteristics such as the many species available to the local people as a forest resource and also sufficient biomass volume availability of VP forests relative to people's participation. Local rules were important for the functioning of VPs, and the existence of chowkidar was also important for its compliance. The most useful tree species for local people was Banji oak ( $Q$. leucotrichophora) and every village had an oak forest of at least 0.39 ha area and $11.6 \mathrm{~m}^{2}$ of basal area per household. Further, the VP forest size and the basal area of trees influenced the people's participation in forest management. However, a much larger size of the VP forest land, such as in the case of G village, at 3.95 ha area and $110.7 \mathrm{~m}^{2}$ of basal area volume per household, resulted in a decline in the people's motivation for forest management. Agrawal (2001) referred to the reasonable level of forestland endowment which was around 0.5 hectare per household. Thus, it is important for local people to be endowed with a suitable size VP forest for better forest management.

In addition, it was observed that older VPs, such as the ones in $\mathrm{G}$ village, $\mathrm{K}$ village and $\mathrm{M}$ village, have created employment opportunities for their villagers in the form of the VP chowkidar, who was completely supported by all households in the VP village. This has a better impact on not only employment opportunities but also on the strength of the people's decision and their self-interest in forest management. Moreover, all householders in the community were paying toward a salary for the local chowkidar. In $\mathrm{K}$ village, the chowkidar was a local woman, who was an average forest user but who also became a 'watchwoman' for the K village VP forest during the period of her duty. She was the representative of women, who were the majority users of NTFPs (non-timber forest products), and was someone who grew up in the area and could therefore better understand forest conditions from the aspect of a local user; and could create various local forest rules in $\mathrm{K}$ village. Furthermore, local people in K village organized "animal grazing tours" enlisting residents during the dry season and some of members accompanied them in order to make their livestock healthier. Additionally, this also helped strengthen the relationship with local villagers.

Further, it was found that better resource and forest dependence stimulated people's participation in forest commons. Furthermore, a higher education of the householder increased the level of participation. The factors for an LPG user who had sufficient income from householders were mostly positive. As for caste, a higher proportion of upper castes such as Brahmin was significantly positive and SC was negative, it could be related to a large portion of $\mathrm{MC}$ members.

Based on the above-mentioned analyses, a strategy of sustainable forest management could be derived from a consideration of livelihood benefits and decision-making autonomy. It seems reasonable to suggest that people's participation in forest management is conditioned by a high dependency on forestry because people need 
resources. The most useful forest resources were Banji oak, which was utilized for fuelwood, fodder and timber. These kinds of forest resources were collected by women; hence women's presence in VPs; and women's MC members had a positive effect on forest governance (Agrawal 2009). On the other hand, women in K and G villages decreased their level of participation at the management level, and it also meant that they were busy managing their own households, and showed less concern on village affairs. Having improved the chance of a successful start of forest management, the case of $\mathrm{K}$ village revealed more rules and the strong leadership of the sarpanch. It meant most successful VPs, such as in K village; served as an example for other villages to extend the process of better CBFM. Transparency of MC for the VP members is also an important aspect for success as well.

In order to improve forest management practice in India, it could be indicated that an enhancement of the mutual relationship between village VPs and the local FD is essential. Other VPs that lack any governmental/NGO's support were not selected in this research as case examples; and these VPs need to be technically supported in order to maintain better forest management by the FD. However, when the forest bureaucracy is characterized by centralized efforts, it means the state government has much control over the VP management, and local governance becomes disempowered (Sarin 2001; Nagahama et al. 2016b). Furthermore, it was existing afforestation activities, which had a better impact on reforestation and on the environment. This would also relate to the "Reducing Emissions from Deforestation and Forest Degradation (REDD+)" program, assuming that the government of India adopts this mechanism to increase forest carbon stock.

\section{Conclusions}

The results obtained through long-term field visits and interviews/questionnaires and analyses in the four VPs cases lead us to summarize this new significance of better conditions for collective management around forest commons as follows: Firstly, more VP rules, transparency and compliance at village level meant recognition of the $\mathrm{MC}$ and that resulted in their higher performance. Secondly, a reasonable size of forestland endowment encouraged people's participation; however, too large a size and the species of oak for fuelwood and fodder discouraged people's participation. Thirdly, a high dependence on fuelwood/firewood was also a factor in people's participation. Fourthly, migration meant that the remaining residents of the community experienced the erosion in population at hilly and mountain area. It is concluded from this study that there was a successful forest management in context of VPs that hinged on these factors. At the same time, the VPs have an important role to play in maintaining the livelihood of people who depend on the forest in rural communities.

\section{Acknowledgments}

The field survey in India would not have been possible without considerable cooperation from the local villagers in Uttarakhand state, and all the respondents who kindly answered to the questions. Special appreciation is given to Dr. G.C.S. Negi and to the many researchers from G. B. Pant Institute of Himalayan Environment and Sustainable Development in Almora for academic advice during the field surveys every year. Great appreciation is due to the Indian NGOs, RELK in Dehradun, CHEA in Nainital and Earthwatch Institute India-Delhi, and for their kind support in developing the field survey and VP visits. Authors would also like to thank Prof. Takeshi Sakurai from the University of Tokyo for supporting this research by sharing his expertise and knowledge and technical skills in statistical analysis. We also thank Mr. Jyoji Yoshida from the Japan Forest Association for technical information of the forest inventory.

\section{References}

Agrawal, A., \& Ribot, J. C. (1999). Accountability in decentralization: a framework with South Asian and African Case. The Journal of Development Area, 33(4), 473-502.

Agrawal, A. (2001). The regulatory community. Mountain Research and Development, $21(3), 208-211$. https://doi.org/10.1659/0276-4741(2001)021[0208:TRC]2.0.CO;2

Agrawal, A. (2005). Environmentality: Technologies of government and the making of subjects. Duke University Press, Durham.

Agrawal, A. (2007) Forests, governance, and sustainability: Common property theory and its contributions. International Journal of the Commons, 1(1), 51-76. https://doi.org/10.18352/ijc.10

Agarwal, B. (2009). Gender and forest conservation: The impact of women's participation in community forest governance. Ecological Economics, 68, 2785-2799. https://doi.org/10.1016/j.ecolecon.2009.04.025

Balooni, K., Ballabh, K., \& Inoue, M. (2007). Declining instituted collective management practices and forest quality in the central Himalayas. Economic and Political Weekly, 42, 1443-1452. 
Ballabh, V., Balooni, K., \& Dave, S. (2002). Why local resources management institutions decline: A comparative analysis of Van (Forest) Panchayats and Forest Protection Committees in India. World Development, 30, 2153-2167. https://doi.org/10.1016/S0305-750X(02)00126-2

Bitterlich, W. (1984). The Relascope Idea. Relative Measurement in Forestry. Commonwealth Agricultural Bureau, UK, 242 pp.

Chakraborty, M. (1995). An analysis of the causes of deforestation in India. In K. Brown, \& D. W. Pearce (Eds.), The Causes of Tropical Deforestation (pp. 226-239). University College Press, London.

Gairola, H., \& Negi, A. S. (2011). VPs in Uttarakhand: A perspective from practitioners. In Y. Gokhale, \& A. K. Negi (Eds.), Community based Biodiversity conservation in the Himalayas (pp. 33-45). The Energy and Resource Institute, New Delhi.

Government of India. (2011). Census of India: http://censusindia.gov.in/

Guha, R. (1983). Forestry in British and post British India: A historical analysis. Economic and Political Weekly, $18,1949-1947$.

Harman, H. (1967). Modern Factor Analysis. The University of Chicago Press, Chicago.

Hill, J., \& Curran, P. (2003). Area, shape and isolation of tropical forest fragments: Effects on tree species diversity and implications for conservation. Journal of Biogeography, 30, 1391-1403. https://doi.org/10.1046/j.1365-2699.2003.00930.x

Lise, W. (2000). Factors influencing people's participation in forest management in India. Ecological Economics, 34, 379-392. https://doi.org/10.1016/S0921-8009(00)00182-8

Nagahama, K., Saito, K., Masuda, M., Ota, M., Gairola, H., Kala, S. K., \& Rakwal, R. (2016). Forest commons use in India: A case study of van panchayat in the Himalayas reveals people's perception and characteristics of management committee. Environment and Ecology Research, 4(3), 128-139. https://doi.org/10.13189/eer.2016.040304

Nagahama, K., Satya, L., \& Saito, K. (2016). The Van Panchayat Movement and Struggle for Achieving Sustainable Management of the Forest: A Case Study of Uttarakhand in North India. SDRP Journal of Earth Sciences \& Environmental Studies, 1(3), 61-70. https://doi.org/10.15436/jeses.1.3.1

Ota, M., Antilb, S., Bhattacharya, P., \& Masuda, M. (2014). Presence and effectiveness of material benefit provisions under joint forest management in India: The cases of world bank-aided village forest committees in Madhya Pradesh. Forests, Trees and Livelihoods, 23(3), 159-174. https://doi.org/10.1080/14728028.2014.886532

Sarin, M. (2001). Disempowerment in the name of 'participatory' forestry?. Village forests joint management in Uttarakhand. Forests, Trees and People. Newsletter 44.

Saito-Jensen, M. (2008). Do local villagers gain from joint forest management? Why and why not?: Lessons from two case study areas from Andhra Pradesh, India. International Cooperation Agency, Tokyo.

Singh, K., \& Ballabh, V. (1991). People's participation in forest management: Experience of Van Panchayat in UP hills. Wastelands News, 7:5-14.

UFD. (2007). Van panchayat Atlas 2007. Forest Department, Uttarakhand, Dehradun.

UFD. (2005). The Uttaranchal Panyayati Forest Rules, 2005. Forest Department, Uttaranchal. Dehradun.

UFD. (2013). Uttarakhand Forest Statistics 2012-2013. Forest Department, Uttarakhand. Dehradun.

\section{Notes}

Note 1. To communicate effectively in the local language, Garhwali in Garhwal division and Kumaoni in Kumaon division, using a local interpreter.

Note 2. All villagers are the members of each VP by definition.

Note 3. In this area, Uttarakhand, the local people cannot change or move their residence easily. According to our interviews in 2012-2015, their residence was inherited through their ancestors where they had started to live more than 500 years ago. Even though some households need to move due to work or education, when the duty (work/job) is over, they return to their homes in the village. Furthermore, the first author stayed in D village every year and she indeed knows the villagers faces/names. In reality, some of the household members do not 
live in the village, and every household has remained unchanged for several years. Therefore, we think only some year's span/period is not a big change.

Note 4. This was developed by Walter Bitterlich (1984), an Austrian forester, who referred to plotless sampling based on basal area of trees and angle point sampling as the "Bitterlich method".

Note 5. This woman has retired from the position of the VP leader and the status was inherited by a younger male after our survey.

\section{Copyrights}

Copyright for this article is retained by the author(s), with first publication rights granted to the journal.

This is an open-access article distributed under the terms and conditions of the Creative Commons Attribution license (http://creativecommons.org/licenses/by/4.0/). 